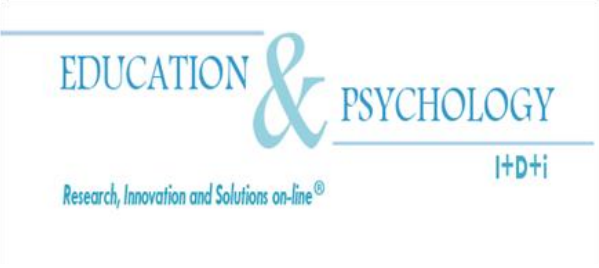

\title{
Problem-based Educational Environments: A Case Study in e-Commerce and Business Planning
}

\section{Olga Megalakaki ${ }^{1}$, Sofoklis Sotiriou ${ }^{2}$, Stavros $_{\text {Savas }}{ }^{2}$ and Yannis Manoussakis ${ }^{3}$}

1. University of Picardy, CLEA, Chemin du Thil F80025 Amiens Cedex 1, France.

2. Ellinogermaniki Agogi, Doukissis Plakentias 25, GR 15234 Chalandri, Greece.

3. University of Paris XI, Orsay, LRI, Bât. 490, 91405 Orsay Cedex, France.

\section{France/ Greece}




\section{Abstract}

Introduction. The purpose of the present study was to explore the educational and cognitive aspects of an innovative approach to Internet use within an interdisciplinary, integrated framework for activities set up to enable students to acquire knowledge informally. These activities had the potential to provide real-world results through a model that was easily applicable in current educational practice.

Method. Adopting a constructivist, "learning by doing" approach, a network of five European secondary schools and educational and technological research institutes developed a webenabled application for teaching various topics related to the e-commerce of agricultural products (AGROweb). This generated a business microcosm in the different schools, allowing students to have contacts with producers, win orders via the Internet and deal with payment and shipping issues. This marketplace was supplemented with a flexible virtual environment where students and teachers could continuously discuss and exchange ideas, and familiarize themselves with the new interactive tools.

Results. The AGROweb project forced students to tackle the problems of the real business world (i.e., establishing contacts with producers, winning orders via the Internet, handling shipping-related issues and payment requirements). For the students, working on the project gave them a desire to broaden their knowledge of computing at various levels, namely web design, animation, software development, databases, and so on. During the project, teaching and learning were no longer perceived of as opposites, but instead as complementary activities.

Conclusion. Technology-based learning environments like AGROweb provide opportunities for acquiring both declarative and procedural knowledge. Similarly, their multidisiplinarity helps learners to develop general strategies and to transfer these strategies from one specific context to another. However, a very careful assessment is needed whenever changes and new learning strategies are involved, in order to measure the impact of these changes from a psychological and educational point of view and define the formal directions to follow.

Keywords: New technology, Constructivism, e-Commerce, Learning-by-doing 


\section{Ambientes Educativos Basados en Problemas: Un caso de estudio en e-Commerce y Planificación de Negocios Resumen}

Introduccion. El propósito del presente estudio fue explorar los aspectos educativos y cognitivos de un marco integrado de actividades organizadas con el fin de permitir a los estudiantes adquirir conocimientos de manera informal. Estas actividades tuvieron el potencial para proporcionar resultados del mundo real, a través de un modelo interdisciplinario que fue fácilmente aplicable en la práctica educativa actual.

Método. Adoptando un enfoque constructivista, "aprender haciendo", una red de cinco escuelas secundarias e institutos europeos de investigación educativa y tecnológica desarrollaron una aplicación web habilitada para la enseñanza de diversos temas relacionados con el comercio electrónico de productos agrícolas (AGROweb). Esto generó un microcosmos de negocios en las diferentes escuelas, permitiendo a los estudiantes tener contactos con los productores, obtener pedidos a través de Internet y hacer frente a problemas de pago y envío. Este mercado se complementó con un entorno virtual flexible donde alumnos y profesores podían discutir e intercambiar ideas de forma continua, y familiarizarse con las nuevas herramientas interactivas.

Resultados. El proyecto AGROweb forzó a los estudiantes a atacar los problemas de negocios del mundo real (ej. establecer contacto con productores, obtener pedidos a través de Internet, manejar cuestiones de envíos, requerimientos de pago). Trabajar en este proyecto brindó a los estudiantes un deseo de ampliar sus conocimientos en computacion en distintos aspectos, por ejemplo, diseño web, animación, desarrollo de software, bases de datos, etc. Durante el proyecto, enseñar y aprender no fueron percibidos como opuestos, sino más bien como actividades complementarias.

Conclusión. Ambientes de aprendizaje basados en tecnología como AGROweb proveen oportunidades de adquirir conocimientos tanto como declarativos como procedurales. Similarmente, su multidisciplinariedad ayuda a los alumnos a desarrollar estrategias generales y a utilizar estas estrategias de un contexto específico a otro. Sin embargo, una evaluación cuidadosa es necesaria siempre y cuando nuevas estrategias de aprendizaje y cambios aparezcan, justamente para medir el impacto de estos cambios desde un punto de vista psicológico y educacional, y luego así, definir que dirección seguir.

Palabras-clave: Nuevas tecnologías, constructivismo, comercio electrónico, aprender haciendo.

Recibido: 07/12/11 Aceptación inicial: 28/12/11 Aceptación final: 20/03/12 


\section{Introduction}

Today it is widely acknowledged that information and communications technology (ICT) can play an important role in the learning process. The growing familiarity of teachers and students with new technology, the increasing degree of transnational cooperation, and the introduction of new cross-disciplinary subjects, where interactions constitute significant driving forces, present new opportunities, but also challenges for school practices. In all cases, new technology is seen not as a substitute for conventional teaching but rather as an "add-on" that has to justify its implementation in the school curriculum through the qualitative upgrade it offers. The Internet and the web are increasingly being used in various forms as mechanisms for flexible learning, by erasing any geographical, time and participation boundaries (McIsaac \& Gunawardena, 2001). Many cognitive theories of human learning are concerned with flexibility, discourse, activity and conversation, and how these can influence the design of multimedia learning environments (Eklund \& Woo, 1998). Cognitivists point out that hypertext structures reflect a map of knowledge in the human brain according to a cognitively based theory and thus facilitate learning (Jonassen, 1992).

For their part, social constructivists claim that the development of partnerships and collaborations plays an important role in knowledge construction (Coll, Rochera, \& Colomina, 2010; Jonassen, 1994; Megalakaki, Savas, \& Sotiriou, 2010; Resnick, 1991; Thurston, Van de Keere, \& Topping, 2006). Underwood and Underwood (1999) and Zhao and Frank (2003) reported better performances whenever students worked in pairs resulting in the exchange of ideas between partners. Social models of learning and communities of practice were examined by Wenger (1998). According Wenger and Snyder (2000), communities of practice are informal groups of people who are occasionally brought together through a shared passion. Wenger's model of a social theory of learning is comprised of four basic components: community (social configurations), meaning (individual's ability), practice (shared social and historical resources) and identity (conceptual changes on an individual level). Wenger (1998) identified several practices and processes characterizing learning, namely: "1) Evolving forms of mutual engagement: discovering how to engage, what helps and what hinders; 2) developing mutual relationships, defining identities, establishing who is who, who is good at what, who knows what... Understanding and tuning their enterprise by aligning their engagement on it...; 3) produc- 
ing or adopting tools, artefacts, representations; 4) recording and recalling events; inventing new terms and redefining or abandoning old ones; 5) telling and retelling stories, creating and breaking routines" (p. 95).

Communities of practice have a crossover interest within what people call "virtual communities". In virtual communities, people come together and share their common values and interests through email lists, bulletin boards, chat rooms, videoconferencing, and so on (i.e., they engage in a joint activity). Engagement is acknowledged to be one of the critical conditions for learning through social interaction in the domains of educational psychology (Nystrand \& Gamoran, 1991; Pintrich \& De Groot, 1990; Vygotsky, 1978) and technology-based learning environments (Hannafin et al., 1996; Hmelo et al., 1999; Persell, 2004). Okolo and Ferretti (1996) found that when students work in virtual communities, they share the process of constructing ideas, instead of working on their own. This increases motivation, knowledge, perception and personal efficiency.

\section{Constructivist approach}

Hypermedia-based learning environments afford opportunities for innovation and renewal in the design and development of flexible and distance learning programmes. They also shed a useful light on the current educational debate, particularly with regard to constructivist approaches to learning. These environments encourage learners to strive toward the learning goal and assess their solutions using strategies such as brainstorming, trial and error, practice and discussion.

In the traditional academic approach, students first have to learn a set of facts, rules and examples. These then form the basis for achieving a comprehensive understanding of the relevant phenomenon. This declarative knowledge is therefore the first, important step in the comprehension process. However, students do not really assimilate the subject and are thus unable to apply this knowledge later on. In other words, in the traditional educational setting, students do not learn how to transform their declarative knowledge into procedural knowledge. It was out of this flaw in the instructional approach that constructivism was born (i.e., exposing students to experiences that trigger insights, thus leading to a better understanding of the phenomenon as a whole; Hanley, 1994). The key idea is that students are better able to master, retain and generalize new knowledge when they are actively involved in constructing that knowledge through learning-by-doing. This 
metacognitive process allows students to transfer their newly acquired problem-solving skills to novel problem situations. The learning process can thus be described as the acquisition, comprehension and use of information.

Constructivist learning theory is based on the assumption that learners actively construct knowledge based on what they already know (Kanuka \& Anderson, 1998), as they attempt to make sense of their experiences rather than passively receiving knowledge. The central figure in the learning environment is therefore the learner, rather than the teacher (Tearle et al., 1999). The teacher takes on a new role of organizing information and re-conceptualising the curriculum design in order to engage the student's interest and enable active exploration to take place (Brown, 1997; Hanley, 1994). According to Tenenbaum et al. (2001), "the constructivist approach views knowledge as an entity, which is mentally constructed via the actions and experiences that the learner undergoes with the immediate learning and broader social environments. Knowledge is actively constructed by the interaction between the learner and external objects through adaptation of and to the experiential world" (p. 89). Tenenbaum et al. (2001) highlighted seven components of constructivist teaching and learning, namely 1) arguments, discussions, and debates, 2) conceptual conflicts and dilemmas, 3) sharing ideas with others, 4) materials and measures targeted toward solutions, 5) reflections and concept investigation, 6) student needs, and 7) making meaning, real-life experiments, and connections.

Anderson and Spigner-Littles (1999)'s observations of adult learners also tend to support constructivist learning theory, "in that we found knowledge to be developed internally, rather than simply transmitted by an instructor to a passive student. We also found that learning occurs most effectively when the mind filters incoming information, and connects that information to past knowledge and current relevance. Learners must construct their own schemas... and solutions to problems by actively revising, restructuring, experimenting with, and placing the new information into their existing cognitive structures. As a result, effective learning is based on reflections, personal insight, and permanent change in behaviour..." (p. 204). 


\section{Teaching e-commerce and business planning}

Many studies have been carried out on various aspects of electronic commerce (Swatman \& Chan, 2000; Ngai \& Wat, 2002), such as the relationship between virtual communities and e-commerce (Lipnack \& Stamps, 1997; Tapscott, 1999; Turban et al., 2000). Woodard (2002) and Joyce (2000) developed flexible models for teaching ecommerce, combining both theoretical concepts and practical hands-on advice.

Concerning teaching methods, Rosenbaum (2000), described a problem-based learning method in a virtual economy. This teaching approach involved the development, testing, implementation, and use of a secure web-based environment in which university students experienced e-commerce. The learning environment developed by Rosenbaum used an approach called "problem-based learning" (Barrows, 1986). This approach is rooted in the constructivist model and its key idea is that students learn by tackling problems, just as professionals do in real life. Several researchers have suggested that transplanting a real-world problem to the classroom might be a valuable addition to the curricula of various disciplines, including medicine and computer science (Duffy \& Cunningham, 1997; Larsen \& McInerney, 2002; Rosenbaum, 2000; Savery \& Duffy, 1995). This approach is eminently suited to teaching e-commerce, due to the nature of the course.

For his part, Hawryszkiewycz (2004), explored new trends in learning management systems and ways of supporting them using information technology. He made a distinction between active and passive learning management systems. Management systems are said to be passive if they require instructional material to be set up by instructors. An active learning management system, on the other hand, helps learners to develop and follow a learning plan that will allow them to meet their learning objective.

Concerning more practical approaches, Angeles and Adams (2000) investigated the use of electronic catalogues and retail shop fronts as part of a concrete collaborative class project on e-commerce, they reported positive results, in terms of achieving the goals of collaborative inquiry, team-based and active learning, the constructivist educational approach, and learning-by-doing. Dhamija et al. (1999), tested an e-commerce course on university students from a variety of academic disciplines. Their web-based online marketplace allowed students to become virtual vendors, consumers, or corporate executives, making and receiving e-payments, negotiating with banks, and addressing social and policy tensions. The difficulties involved in teaching e-commerce personalization technol- 
ogy at postgraduate level have been comprehensively discussed by Sicilia (2005). This technology, which includes adaptive hypermedia and information filtering, makes it possible to build and maintain a personalized relationship with a customer or business partner.

The challenges of team-teaching e-commerce in business schools have also been explored (Heath \& Sena 2001; Sena \& Heath, 2002). The distinguishing feature of teamteaching is that a group of instructors (the teaching team) must agree on the course's goals and objectives. In addition, all the team members must share the course administration workload.

\section{The AgroWeb web-based environment}

The AgroWeb project involved the creation of a virtual situated learning environment based on the principles of "learning by doing", in the shape of an e-shop. This helped researchers to investigate the effects of Internet practices on education mediated by social interactions (Hannafin et al., 1996; Okolo \& Ferretti, 1996; Wenger, 1998). It was based on the concept of so-called "situated cognition" (i.e., learning content in the context in which it will be used; Brown et al., 1989). It also adopted a "problem-based learning" approach (Barrows, 1986; Rosenbaum, 2000) and cross-disciplinary features (Dhamija et al., 1999). However, while all previous studies had concerned universitylevel courses, the AgroWeb project was tailored to secondary school-level teaching experiences.

A cross-disciplinary model, AgroWeb e-shop simulated a real-world situation, proposing a series of market-related activities in the classroom. It created an innovative and powerful "learning-by-doing" environment in the form of a virtual classroom related to ecommerce and business planning. It was a distributed digital marketplace that simulated a competitive environment in which could students promote agricultural goods produced locally. Through this crossover platform, students could become sellers and buyers, and the reality of modern economic practices was thus given an educational twist. Students were invited to become sellers, designing, starting up, and operating Internet businesses to promote local agricultural products. It should be noted that the schools belonging to the AgroWeb network were situated in rural areas of Europe. Students from other schools in the network purchased goods. They paid in electronic money and the items were subsequently shipped to them by a company that was sponsoring the specific task. 
This web-enabled application was the fruit of an international collaboration within a network of European secondary schools, university departments of educational psychology, and specialists in the development of educational multimedia. The e-shop included a tool for producing graphic representations of product sales (product performance), in order to compare actual and anticipated performances and everything else that is generally required to monitor the financial activities of a real shop. The e-shop served as an electronic agora, the meeting point for all transactions and exchanges of ideas; the place where the European single market and the European single currency (euro) became a virtual - reality.

The main conceptual characteristics of AgroWeb's approach are presented below:

\section{1) Learning through social interactions within a group. Students were encouraged to} work in groups and collaborate not only with their physically present classmates, but also with their virtual classmates in the other countries participating in the project. For the purposes of the AgroWeb project, the Internet was used as a comprehensive communication tool for collaborative learning, through the development of a special platform (videoconferencing, emails, chat rooms and forums) for exchanging ideas about agricultural products, including cultural and geographical details. These exchanges of content between students from different European schools stimulated collaborative activities, such as the remote design of a common marketing strategy for different European goods. Students were asked to collect appropriate and "marketable" content about the products they were going to sell electronically and to develop a business plan for marketing them, sharing the workload with their virtual classmates. Finally, they determined "bundling" policies with their virtual classmates in the other European countries, in order to attract consumers who wanted to sample a basket of different goods. At the same time, students studied, analysed and compared the actual performance of the products with the performance targets set out in the original business plan. All these activities stimulated dialogue with virtual classmates through the various communication channels the platform offered. During this dialogue, students' questions or comments could be addressed and answered by remotely located classmates or teachers.

2)Development of a cross-disciplinary model. Cross-disciplinarity is crucial for enhancing the effectiveness of education, as it provides a unique way of strengthening learning 
processes such as discovering analogies, similarities, and so on. During all the stages of this project, the students acquired knowledge and skills in subjects such as language, culture, history, geography, mathematics, and economics. For instance, they collected information about the history of the products produced in their areas (in their history lessons). They simultaneously investigated relevant chemical and ecological data about the products they were marketing and about their defining features, compared with their rivals (in chemistry lessons). They designed attractive trademarks for their products in order to market them as effectively as possible (in art lessons). Finally, the products' performance was monitored with the use of the additional features of the e-shop (in civics and economics lessons), giving students the opportunity to assess their strategies and modify their business plans accordingly.

3) Creative e-commerce and business planning learning. Within the framework of the AgroWeb project, the educational content was transmitted not in a theoretical way, but rather in the form of a real-life experience, with topics that were inherently closer to realworld problems. Students became entrepreneurs, finding, promoting, marketing and selling agricultural products from their local areas. They were asked to identify traditional agricultural goods that played a significant role in the history and socioeconomic development of their country. After selecting the most representative products, students negotiated with local producers to acquire a limited amount of goods in exchange for promoting them on the Internet within the framework of the project. Once agreements had been reached, students developed a business plan for each product, taking all the appropriate stages into account: market research, price setting, distribution, promotion policies and shipping. They designed attractive trademarks and web pages to market them as effectively as possible. Particular care was paid to the presentation and promotion of the products, with graphics and animations. AgroWeb's e-shop included a tool for producing graphic representations of product sales, to compare actual and anticipated performances, and everything else that is generally required to monitor the financial activities of a real shop. During the "e-shopping", the performance of the products in the virtual market was monitored on a weekly basis, using the e-shop's additional features. Virtual classmates could easily compare the different promotion strategies adopted in different countries, assess them and, through bulletin board discussions, identify the factors that were affecting product sales. They could then respond immediately, modify their strategies accordingly and subsequently study the impact of their decisions. Students also presented their prod- 
ucts, together with their marketing strategies, in a bulletin that was published throughout the project.

4) Familiarization of the teachers with ICT. Invited experts provided the teachers with effective training, accustoming them to the use of new technology and helping them to incorporate this technology into their teaching practice. The training took place during regular summer-school meetings and online seminars. The consultants provided input on Internet applications, economics and business. The seminars included guidelines for effectively monitoring the students' attitudes during the project.

\section{Objective and hypothesis}

In line with the project's general objectives, its educational framework was designed to support activities and processes for facilitating intentional and thoughtful learning. The main aim of our research was to highlight the impact of the project on the students' social and intercultural attitudes and on the topics related to the project (i.e., the use of new technology, knowledge about Europe, e-commerce, secure transactions and electronic payments). In order to assess the impact of the project, we conducted quantitative and qualitative analyses during its different stages. In the present paper, we present the qualitative analyses.

We hypothesized that the high degree of collaboration and the international character of the project would alter social attitudes, leading to a greater appreciation of teamwork and a higher degree of acceptance of and knowledge about foreign countries. Experience gained in the classroom concerning the use of modern technology would lead to a change in individual behaviour, in that the project's participants would make more conscious use of specific electronic tools (i.e., more or less often). Due to the international character of the project, we also predicted that knowledge about other European countries, specifically those involved in the project, would improve. Finally, we expected to see an improvement in knowledge concerning various aspects of e-commerce. 


\section{Method}

\section{Participants}

A total of 280 students attending academic or vocational schools in five countries (Austria, Denmark, Germany, Greece and Portugal) took part in the different phases of the project. For the purposes of the present paper, we retained a total of 117 academic students, drawn from one class in each of the five countries, who actively participated in all the project phases. The sample had a mean age of 15.54 years and was composed of 62 boys and 55 girls.

\section{Material}

A web platform was created on the basis of four criteria: user friendliness, full interactivity to stimulate the user's engagement, variety in the range of activities and a motivating learning environment. Full details are available at:

http://www2.ellinogermaniki.gr/ep/agroweb/

The AgroWeb platform included:

- The e-shop featuring descriptions of the products and allowing full commercial transactions to take place, (see home page in Fig. 1);

- Links to related sites containing information about the regions and their history;

- Notes on promoting the products and ways of monitoring and assessing sales;

- Teachers' and students' bulletin boards;

- Online documents (transparencies, texts, etc.) for teacher training;

- Electronic editions of e-AGRO magazine.

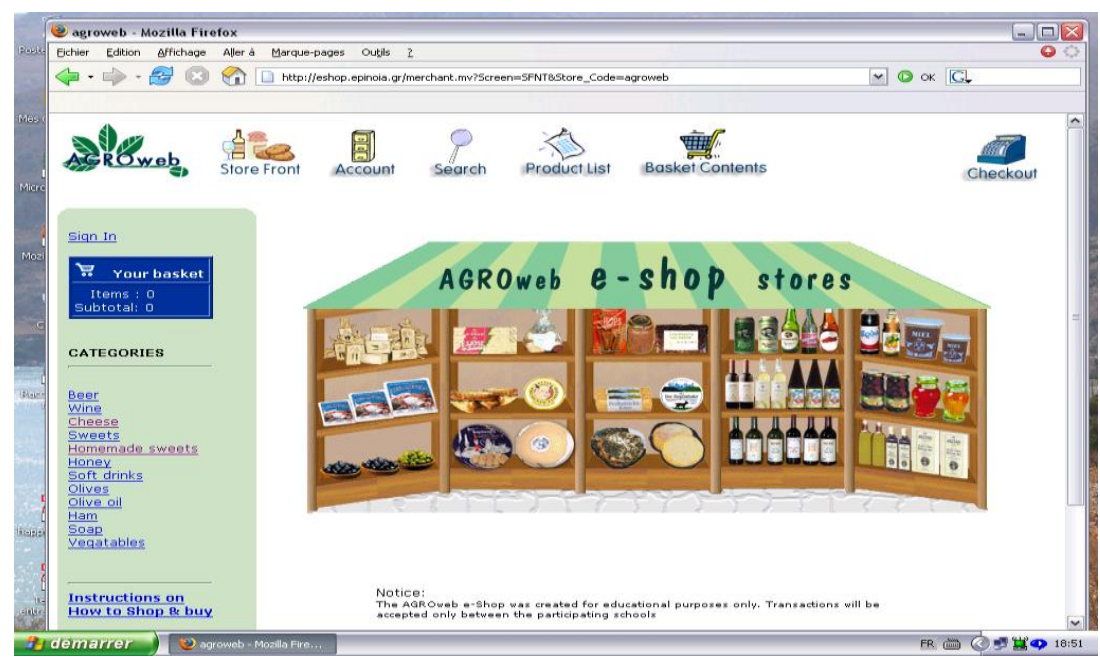

Figure 1. The home page of the AgroWeb e-shop 


\section{Procedure: Implementation of the AgroWeb project}

The two-stage project lasted for two full academic years, each stage corresponding to one academic year. The first year was spent preparing activities related to the development of the platform and carrying out teacher/student training. The second year covered the final test runs, commercial transactions between students, observations of students' activities and the drafting of self-reports by teachers.

\section{Data analysis and qualitative project assessment}

Part of the project assessment was based on a qualitative data source, in the form of teachers' self-reports about their experiences. Detailed observations were made of students' activities as they performed the different tasks. Issues about students' social and intercultural attitudes, their use of new technology, cross-cultural knowledge and ecommerce were discussed and assessed by teachers at the beginning and end of the project.

\section{Results and Discussion}

\section{Working in groups and social interactions between students}

Class spirit and the level of enthusiasm for the project were quite extraordinary, with most students expressing the desire to participate in any similar future projects. In most of the schools, tools were developed to facilitate virtual interactions and communication between students (forums, web pages, etc.), open days were held, and students either visited or played host to partner institutions. Some schools used the Internet "agora" for posting messages or videoconferencing for online communication. Through these types of interaction, project participants developed a "team spirit" which pervaded the way they collaborated, reflected, and articulated their ideas. By this means, they established their identity and defined their place within the group. Thus, it became obvious that the exchange and pooling of knowledge is extremely efficient, as no individual can ever be omniscient. In line with Rosenbaum's findings (2000), the sense of shared progress and shared goals, the feeling of teamwork, and the group dynamics brought about substantial advances in learning. 
Many teachers observed that students spent an increasing amount of time working in groups. Accordingly, by the end of the project, they worked far more often with their classmates than they had done at the outset. As one teacher wrote, "Very early on in the course of the project, after the students had decided on the variety of tasks involved in the project, a division of labour was agreed on for certain of those tasks. Thus, each of the students volunteered for a task according to their inclinations and interests: programming, web design, taking photos, writing descriptive and advertising texts. All members were active in choosing products, seeking out, contacting (by mail, telephone), visiting and interviewing producers, developing sales plans, etc. Also, through some negative experiences, the students have become aware of the requirements for successful teamwork: reliability, a sense of responsibility, coordination...".

Such remarks confirm, as constructivist approach, that getting children to work together with other children in collective learning efforts brings benefits (Johnson et al., 1981; Rysavy \& Sales, 1991; Zhao \& Frank, 2003). The Internet was regarded as a communication and conversational medium par excellence (Chen \& Gaines, 1998) and as a mediated environment allowing for a range of cooperative interactions (Pallof \& Pratt, 1999).

\section{Information about European partners}

The students gained insight into the cultural diversity of European countries and the reality of Europe today (e.g., the "European team spirit"). This was achieved via the home pages of the partner schools, as well as the partner teams' presentations of and information about the local markets, producers and products, and about customs and traditions. In addition, they experienced a sense of community, with the partner teams sharing the ambition to establish a common e-shop (i.e., a miniature version of the common market), supported by a common currency (i.e., the euro).

\section{Interaction between students and teachers}

During the project, teaching and learning were no longer perceived of as opposites, but instead as complementary activities. It became increasingly obvious that any partnership between students and teachers depends on the students' willingness to cooperate, and teachers must offer them an opportunity to use their own initiative in both curricular and 
extracurricular activities. Flexibility is a key feature of the new role the teacher has to play, which is far more complex than traditional teaching (Ringstaff \& Kelley, 2002). The advantages of this collective and flexible effort are that children are able to reflect on and elaborate not just their own ideas, but those of their teachers as well.

The fact that many parts of the project were carried out on top of regular schoolwork also proved that collaboration between students and teachers can be extended beyond the school context (i.e., it can take on the status of an extracurricular activity without causing any opposition from the students). Thus, the students did not see their teachers solely as givers of knowledge, but as partners and even knowledge recipients. As one teacher wrote, "When I introduced the project to my12 ${ }^{\text {th }}$-grade geography class, most of them were enthusiastic and eager to take part in the project. One or two of the girls were a little reluctant because they felt insecure about their ability to use a computer. However, it was the teacher - myself - who felt most insecure of all, since I had neither knowledge nor experience of computing - even though a colleague who was far more knowledgeable about using computers, the teacher of computer sciences, had agreed to join the team for the first year. When I told the students about my apprehensions, they immediately assured me of their support and offered to pass on their knowledge (i.e. to teach me). The agreement, then, was that they would contribute their expertise in computing and I my knowledge in the fields of economics, geography, and English, the lingua franca."

In this way, the relationship between teachers and students changed, while the framework bringing them together became independent of time and place. Teachers learned along with their students everywhere and all the time. This is in line with Dillon and Granger (1998)'s description of the new role of the educator in the context of distance learning: "I am not a teacher of 'things', I am an 'orchestrator' of ideas. My educational institution is not a physical place with classrooms and trees, but a 'hub' of resources no longer constrained by time and place. My students are no longer 'my' students, we are all students together." 
Attitudes toward new technology

Some parts of the project generated considerable motivation and enthusiasm for investing further in new technology. For all the students, working on the project gave them a desire to broaden their knowledge of computing at various levels, namely web design, animation, software development, databases, and so on. These results are in line with previous results on the benefits of ICT (Coll et al., 2010; Garcia-Lopez \& Romero, 2009; Hermans, Tondeur, Van Braak, \& Valcke, 2008; Schrire, 2006; Tondeur, Van Braak, \& Valcke, 2007). Many students searched the Internet for software and for information concerning the design and development of web pages. As one teacher observed, "To all of the students, work on the project has given an impulse to widen their knowledge of computing, at various levels. One of the girls, 'the photographer', has developed an interest in creating computer animations, as a fellow student has shown her how to use the appropriate software. Others have searched the Internet for software supporting the design of a sophisticated home page and have created their own personal home pages. As a result of their AgroWeb activities, one of the students is now even considering doing web design as a career".

We also observed a change in the way that students used computers. In particular, at the end of the project, students said they spent less time on games and more time on other activities related to computing, such as word processing, data analysis and image processing. These observations confirmed that one of the main aims of the project had been achieved, namely encouraging students to regard computers as tools for intellectual activity, rather than as machines for playing games. By contrast, participation in the project had no direct effect on many activities related to access to and use of the web, in particular the use of emails, chat rooms, forums and discussions with other schools. This is not so surprising, given that today's students are extremely familiar with the Internet.

\section{Familiarization with the business world and e-commerce}

The AgroWeb project forced students to tackle the problems of the real world of business (i.e., establishing contacts with producers, winning orders via the Internet and handling shipping-related issues and payment requirements). As the students were at an age where they had to start thinking about their future careers, this personal contact with producers, business people, transport companies and financial institutions was of great 
importance. Students had to learn how to prepare a business plan, write a proper business letter, choose the appropriate marketing style, deal with customs and excise authorities, negotiate overdraft facilities with banks, register as a junior enterprise, prepare products for trade fairs and seek sponsorships. They realized the importance of considering the producers' expectations in terms of reliability, appointment keeping, efficient use of time, and so on. They became aware that owning and running even a small business is a huge and complex task, bringing with it considerable responsibilities, involving personal commitment, considerable investment of time and money, knowledge about work organization and accounting, and human resource management. Getting to know the production processes in detail alerted them to the cost and importance of sophisticated machinery in the production of even seemingly simple products, such as wine and apple juice.

In contrast to the normal use of computers, students were still reluctant about matters concerning electronic payment and security. They doubted that the Internet was entirely secure, but had considerable difficulty explaining why it was not. The three possible causes suggested by their teachers (i.e., the dealer might cheat, the network is not secure, computers are not secure) seemed to have no direct effect.

Students became aware of the logistics needed for the proper distribution of ordered goods - one requirement, among others, for successfully running an e-shop. Experience showed that the delivery of goods can be a problem. The project also encouraged the students to use e-commerce in everyday life for purchasing items such as tickets for the theatre or cinema, plane, ferry or train tickets, and books.

\section{Impact on teachers}

Although the work on the project was carried out on top of their regular teaching workload, it proved extremely rewarding for teachers in more than one respect. One of the innovative aspects of the project was the idea of having to explain cross-disciplinary objectives, especially for subjects such as computer science, geography, the arts, English, web design, economics, and so on. The most obvious result, however, is that most of the teachers not only overcame their reluctance about computing but started to use computers and the Internet for schoolwork in general, helping to develop a positive attitude towards the use of ICT for learning (Hermans et al., 2008; Tondeur et al., 2007). Several times, the students even came to their teachers' rescue when the latter had problems with the 
computer. AgroWeb reinforced the existing sense of partnership between students and teachers, and affected the educational approach that was adopted. As one teacher commented, "The strong sense of partnership between the students and myself, the pooling of knowledge has been one of the most rewarding experiences of my teaching career and has affected my approach to all other students insofar as I have come to encourage them even more than in the past to use their initiative and play an active part in class."

\section{School innovations}

In most of the schools, based on their experience with the project, new courses on ecommerce and web development are to be added to the curriculum. School administrations had the opportunity to see the effects of integrating information technology with the curriculum and the enthusiasm generated among the students. They are convinced today that the Internet will become a major source of knowledge and can easily be integrated as an additional tool in educational and scientific programmes. As one teacher wrote, "We will add a new course on e-commerce to our curriculum, based on our experience with this project. In addition to the new course, we will add an A GROw eb-type project to our computer science/business course plan (permanently) - and we plan to promote our products at our bi-annual 'May Day' celebration next year."

Briefly, in the long term, the Internet will complement the conventional teaching tools. There are signs that such innovation may increase the students' interest even in traditional subjects, such as geography. This particular subject seems particularly relevant, as one of the schools' tasks is to broaden young people's horizons, and improve their knowledge and understanding of other countries.

\section{Conclusion}

The school of today has to offer not only formal but also informal learning. Students must be prepared not only for the acquisition of knowledge, but also for fast and efficient integration into society.

With the arrival of new technology, teachers must now view the acquisition of knowledge as a process of continuous research, where they have to share both the difficulties and the results with their students. In their new role, teachers have to develop mul- 
tiple skills (Hermans et al., 2008), model concepts and skills for learners, build the curriculum and scaffold learning. They have to teach their students not just knowledge, but "how to learn", and favour teamwork allowing for social engagement, freedom of expression, exercise of power and contributions to the common good of the community. We must accept the idea that teacher and learner no longer have to be in the same place at the same time. Information technology and fast-changing high-tech sectors such as ecommerce may largely facilitate such transitions. First of all, however, teachers must become familiar with the culture of cyberspace, living in the present not allowing their knowledge to become obsolete, but instead learning how to keep it up to date.

In this technological age, the role of the student also needs to be revised. Students are active participants, and their ability to virtually or physically collaborate with their classmates influences their learning efficiency. The passive knowledge receivers of yesterday are now being asked to work together in groups in order to perform shared activities and attain common goals. In this way, learners are encouraged to collaborate, reflect, and articulate their knowledge. Their motivation grows and their efficiency in developing general strategies improves. Students are strongly encouraged to use techniques such as identifying problems, planning, and checking, thus enhancing various cognitive skills. When a web-based program is designed to foster cooperative learning, learners can benefit both instructionally and socially.

Finally, school also has to change vis-à-vis society. Schools are being allowed to remain in the old system, while students are living in the present. There are signs that this gap creates a mismatch between schools and children. It creates more obstacles between school and society than it overcomes. Then again, technological skills and innovative elements may increase the students' interest and learning efficiency. School administrations must permanently be on the lookout for new opportunities, and assess the effects of integrating information technology into the curriculum, capitalising on the enthusiasm this generates among students and having the courage to break with tradition, where necessary. The theoretical foundations and a collective international experience for such changes exist and schools must take them into consideration.

Briefly, technology-based learning environments like AgroWeb make it possible to develop procedures and provide opportunities for acquiring both declarative and procedural knowledge. Similarly, their multidisiplinarity helps learners to develop general strategies and to transfer these strategies from one specific context to another. However, a 
very careful assessment is needed whenever changes and new learning strategies are involved, in order to measure the impact of these changes from a psychological and educational point of view and define the formal directions to follow. In conclusion, we can say that new technology may change the way students learn and communicate with the outside world, and can help to overcome certain learning difficulties. However we must not forget that fresh difficulties may also arise, especially those related to the use of this new tool (Zhao \& Frank, 2003). Furthermore, its fast-changing character reminds us that every individual has a need for lifelong learning, whatever his or her age or status.

\section{References}

Anderson, C. E., \& Spigner-Littles, D. (1999). Constructivism: A paradigm for older learners. Educational Gerontology, 25(3), 203-209.

Angeles, R., \& Adams, D. (2000). Building electronic catalogs and retail storefronts: Enlivening the electronic commerce course with cooperative learning-based projects. In J. Bourdeau \& R. Heller (Eds.), Proceedings of World Conference on Educational Multimedia, Hypermedia and Telecommunications 2000 (pp. 928-932. Chesapeake, VA: AACE.

Barrows, H. S. (1986). A taxonomy of problem based learning methods. Medical Education, 20, 481-486.

Brown, J., Collins, A., \& Duguid, P. (1989). Situated cognition and the culture of learning. Educational Researcher, 18, 32-42.

Brown, T. (1997). Multimedia in education-Conclusions. Retrieved September 27, 1999 from the World Web:http://129.180.87.4/Units/CurricSt/CSIT513/573/573_12.html

Chen, L., \& Gaines, B. (1998). Modelling and supporting virtual cooperative interaction through the World Wide Web. In F. Sudweeks, M. McLaughlin, \& S. Rafaeli (1998). Network and net play: Virtual groups on the Internet. Menlo Park, CA: AAAI Press/The MIT Press.

Dhamija, R., Heller, R., \& Hoffman, L. J. (1999). Teaching e-commerce to a multidisciplinary class. Communications of the ACM, 42(9), 50-55.

Coll, C., Rochera, M., \& Colomina, R. (2010). Situated uses of ICT and mediation of joint activity in a primary education instructional sequence. Electronic Journal of Research in Educational Psychology, 8(2), 517-540. 
Dillon, C., \& Granger, D. (1998). Guest editorial. The American Journal of Distance Education 12(1), 2-6.

Duffy, T. M., \& Cunningham, D. J. (1997). Constructivism: Implications for the design and delivery of instruction. In D. Jonassen (Ed.), Handbook of research in education, communication, and technology. New York: Macmillan.

Eklund, J., \& Woo, R. (1998). A cognitive perspective for designing multimedia learning environments. In R. Corderoy (Ed.), Proceedings of ASCILITE98 (pp.181-190). Wollongong, Australia: The Printery.

Garcia-Lopez, M., \& Romero, I. M. (2009). The influence of new technologies on learning and attitudes in mathematics in secondary students. Electronic Journal of Research in Educational Psychology, 7(1) 369-396.

Hannafin, M., Hannafin, K., Hooper, S., Rieber, L., \& Kini, A. (1996). Research on and research with emerging technologies. In D. H. Jonassen, Handbook of research for educational communications and technology (pp. 378-402). New York: Macmillan.

Hanley, S. (1994). On constructivism. Available at: http://www.towson.edu/ csme/mctp/ Essays.html

Hawryszkiewycz, I. (2004). Towards active learning management systems. In R. Corderoy (Ed.), Proceedings of ASCILITE98 (pp. 348-356). Wollongong, Australia: The Printery.

Heath, E., \& Sena, P. (2001). The challenges of team teaching e-commerce. In D. Colton, S. Feather, M. Payne, W. Tastle (Ed.), Proceedings of 2001 ISECON Conference (pp. 19-20). Cincinnati, Ohio USA.

Hermans, R., Tondeur, J., Van Braak, J., \& Valcke, M. (2008). The impact of primary school teachers' educational beliefs on the classroom use of computers. Computers and Education, 51(4), 1499-1509.

Hmelo, C. E., Guzdial, M., \& Turns, T.(1999). Computer-support for collaborative learning: Learning to support student engagement. Journal of Interactive Learning Research, 9(2) $107-129$.

Johnson, D. W., Maruyama, G., Johnson, R., Nelson, D., \& Skon, L. (1981). Effects of cooperative, competitive, and individualistic goal structures on achievement: A meta-analysis. Psychological Bulletin, 89, 47-62. 
Jonassen, D. (1992). Designing hypermedia for learning. In E. Scanlon \& T. O'Shea (Eds.). New directions in educational technology (pp. 124-130), Berlin: Springer Verlag.

Jonassen, D. (1994). Thinking technology: Towards a constructivist design model. Educational Technology, 34, 34-37.

Joyce, P. (2000). A Virtual Teaching Environment for Electronic Commerce, Proceedings of the 8th European Conference on Information Systems, Vienna, Austria, 3-5 July, pp. 13681375 .

Kanuka, H., \& Anderson, T. (1998). On-line interchange, discord, and knowledge construction. Journal of Distance Education, 13(1), 57-74.

Larsen, K. R. T., \& McInerney, C. R. (2002). Preparing students for the virtual organization. Information \& Management, 39, 445-456

Lipnack, J., \& Stamps, J. (1977). Virtual teams. New York: John Wiley \& Sons.

McIssac, M., \& Gunawardena, C. (2001). Distance education. In David H. Jonassen (Ed.), Handbook of research for educational communications and technology (pp. 403-437). Mahwah, NJ: Lawrence Erlbaum Associates,

Megalakaki O., Savas S., \& Sotiriou, S. (2010). Mise en œuvre des conditions d'apprentissage dans une perspective constructiviste en utilisant les TIC. Psychologie \& Éducation, 2, 55 70.

Ngai, E. W. T., \& Wat, F. K. T. (2002). Literature review and classification of electronic commerce research. Information and Management, 39, 415-429.

Nystrand, M., \& Gamoran, A. (1991). Instructional discourse, student engagement, and literature achievement. Research in the Teaching of English, 25(3), 261-290.

Okolo, C. M., \& Ferretti, R. P. (1996). Knowledge acquisition and technology-supported projects in the social studies for students with learning disabilities. Journal of Special Education Technology, 13(2), 91-103.

Pallof, R. M., \& Pratt, K. (1999). Building learning communities in cyberspace: Effective strategies for the online classroom. San Francisco: Jossey-Bass.

Persell, C. H. (2004). Using focused Web-based discussions to enhance student engagement and deep understanding. Teaching Sociology, 32(1), 61-78. 
Pintrich, P. R., \& De Groot, E. V. (1990). Motivational and self-regulated learning components of classroom academic performance. Journal of Educational Psychology, 82(1), 3340.

Resnick, L. (1991). Shared cognition: Thinking as social practice. In L. B. Resnick, J. M. Levine, \& S. D. Teasley (Ed.), Perspectives on socially shared cognition (pp. 1-20). Washington, DC: American Psychological Association.

Ringstaff, C., \& Kelley, L. (2002). The learning return on our educational technology investment: A review of findings from research. WestEd RTEC. Retrieved from: http://www.ecs.org

Rosenbaum, H. (2000). Teaching electronic commerce: Problem-based learning in a virtual economy. Journal of Informatics Education and Research, 2(2), 45-58.

Rysavy, S. D. M. \& Sales, G. C. (1991). Cooperative learning in computer-based instruction. Educational Technology Research and Development, 39, 70-79.

Savery, J. R., \& Duffy, T. M., (1995). Problem based learning: An instructional model and its constructivist framework. Educational Technology, 35(5), 35-38.

Schrire, S. (2006). Knowledge building in asynchronous discussion groups: Going beyond quantitative analysis. Computers and Education, 46, 49-70.

Sena, M., \& Heath, E. (2002). Team-teaching electronic commerce: Lessons learned. In Proceedings of 2002 ISECON Conference. San Antonio, TX.

Sicilia, M. A. (2005). Teaching e-commerce personalization technology: The need for a comprehensive view. Journal of Information Technology Education, 4, 85-96.

Swatman, P., \& Chan, E. (2000). Report from the panel on teaching electronic commerce. In 4th Pacific Asia Conference on Information Systems Hong Kong.

Tapscott, D. (1999). Creating virtual value in the network economy. Boston, MA: Harvard Business School.

Tearle, P., Dillon, P., \& Davis, N. (1999). Use of information technology by English university teachers. Developments and trends at the time of the National Inquiry into Higher Education. Journal of Further and Higher Education, 23(1), 5-15. 
Tenenbaum, G., Naidu, S., Jegede O., \& Austin, J. (2001). Constructivist pedagogy in conventional on-campus and distance learning practice: An exploratory investigation. Learning and Instruction, 11, 87-111.

Thurston, A., Van de Keere, K., \& Topping, K. J. (2006). Constructing understanding in primary sciences. Electronic Journal of Research in Educational Psychology, 8(4), 1-34.

Tondeur, J., Van Braak, J., \& Valcke, M. (2007). Towards a typology of computer use in primary education. Journal of Computer Assisted Learning, 23, 197-206.

Turban, E., Lee, J., King, D., \& Chung, H. M. (2000). Electronic commerce: A managerial perspective. Englewood: Prentice Hall.

Underwood, J., \& Underwood, G. (1999) Task effects on co-operative and collaborative learning with computers. In K. Littleton \& P. Light (Eds.); Learning with computers (pp. 10-23). London: Routledge.

Vygotsky, L. (1978). Mind in society. Cambridge, MA: Harvard University Press.

Wenger, E. (1998). Communities of practice: Learning, meaning and identity. London: Cambridge University Press.

Wenger, E., \& Snyder, W. (2000). Communities of practice: The organisational frontier. Harvard Business Review, 78, 139-145.

Woodard, H. (2002). A model for teaching electronic commerce students, Educational Technology and Society, 5(4), 154-159.

Zhao, Y., \& Frank, K. A. (2003). Factors affecting technology uses in schools: An ecological perspective. Americn Educational Research Journal, 40(4), 807-840. 